\title{
Perception of Government Accountants on Current Public Sector Accounting Practices and Implementation of Public Sector Accounting Standards in the Sri Lanka
}

\author{
Vickneswaran Anojan \\ Lecturer (Probationary), Department of Accounting, \\ Faculty of Management Studies \& Commerce, University of Jaffna, Sri Lanka. \\ E-mail: v.anoabt@gmail.com
}

Received: Nov. 29, 2018 Accepted: March 24, $2019 \quad$ Published: June 1, 2019

doi:10.5296/ajfa.v11i1.14469 URL: https://doi.org/10.5296/ajfa.v11i1.14469

\begin{abstract}
The main aim of the study is to find out the perception of government accountants on current public sector accounting practices and implementation of public sector accounting standards in the Sri Lanka. Public sector accounting practices involve with public expenditure, budget preparation, maintain proper accounting records, assets management, public financial management and provide reports on the public expenditure and revenue. Most of the public sector organizations do not prepare final accounts on accrual basis in the Sri Lanka. Primary data used in this study which data collected from government accountants in Sri Lanka. Mean analysis confirmed that there is moderate level of public sector accounting practices and implementation of public sector accounting standards in the Sri Lanka. Correlation analysis confirmed that there is significant relationship between public sector accounting practices and implementation of public sector accounting standards. Implementation of public sector accounting standards are positively impact on the public sector's financial reporting practices and assets management practices in the Sri Lanka. Also below 23 percentage of public sector organizations are preparing final accounts on accrual basis. More than 97 percentage government accountants have ability to prepare annual accounts on accrual basis. Government administrators, policy makers and professional institutions should motivate effective and efficient implementation of the public sector accounting standards which will lead to a healthy public sector accounting practices in Sri Lanka.
\end{abstract}

Keywords: Perception, Government Accountant, Public Sector Accounting, Practices, Sri Lanka. 


\section{Introduction}

Public financial management is an important part of every country. It involves with the national development of the country. Financial statement provides financial information to the economic decision makers. Today economic decision makers are expecting financial and relevant non-financial information for their effective decision making. Public sector organization is one of the high level expenditure organizations in Sri Lanka. Mostly public sector organizations involve with public expenditure here income generation of public sector organization is very low level. A huge amount of money spends for the total recurrent expenditure and total public investment of the country. According to annual report (2017) of Sri Lanka, it can be seen that total recurrent expenditure was Rs. 1,945,575,039,924 and total public investment was Rs. 657,530,018,379 in Sri Lanka. Administrative structure of Sri Lanka has three major structures such as central government, provincial government and local government. Here public sector accounting practices are different in above three structures of the administration. Most of the public sector organizations are preparing their accounts based on cash basis. Payables and receivables do not reflect in the final accounts of the public sector organization. Further it can be seen that most of the public sector organizations do not prepare statement of financial position. Due to that such public sector organization does not know about their total assets and liabilities.

Government accountant has a major role in the public sector accounting practices of Sri Lanka. Most of the public sector organization has government accountant even though there is no government accountant in the Pradeshiya Sabha. There are a number of publications such as public procurement manual, guidelines, financial regulations, administration regulations and circulars which are providing guidance for the public sector accounting practices in the Sri Lanka. There is software for the accounts preparation of public sector organization and software for the salary preparation in the Sri Lanka. There is no a specific software for the assets management of the government organizations in Sri Lanka. Most of the country is trying to adopt accrual basis accounting practices in the public sector. Sri Lanka is trying to adopt accrual basis accounting practices in the public sector. Here provincial council and local authorities start to prepare the accounts on accrual basis. Also government owned public enterprises and companies prepare the financial statements based on accrual basis. Chartered accountant of Sri Lanka has best annual report and accounts awards competition for the public sector. The main aim of the initiation is to improve the quality of the annual report of the public sector and promote accrual basis accounting practices in the public sector. The government of Sri Lanka spends a huge amount of money to give training for the public officers on the public sector accounting practices and accrual basis accounting practices in the public sector. However public sector firms are unable to adopt the accrual basis accounting practices in Sri Lanka.

\section{Literature Review}

\section{a) Theoretical Review}

\section{Public Financial Reporting Practices in Sri Lanka}

Generally government departments are preparing its budget then allocation is allocated 
according to the budget of the particular government department in Sri Lanka. Then fund is released for the central, provincial and local government of the Sri Lanka by the general treasury. Provincial treasury has responsibility to release fund for the provincial and local government of Sri Lanka. Then particular government department has the responsibility to report on its income and expenditure for that particular financial year. Financial year starts on $1^{\text {st }}$ January and end on $31^{\text {st }}$ December of the same year. Department of state account has the responsibility to prepare accounts and publish government final accounts. For example divisional secretariat accounts are prepared by accountant of that particular divisional secretariat office then divisional secretariat accounts send to the chief accountant of district secretariat. Chief accountant has responsibility to accumulate all the divisional secretariat accounts of the district with district secretariat accounts. Then final accounts of the district send to the department of state accounts, general treasury of Sri Lanka. All other government organizations are practicing like above example in Sri Lanka. Most of the government organization is practicing software for their financial reporting which is Computerized Integrated Government Accounting System (CIGAS). According to the financial regulations and treasury circulars most of the government organization has to prepare the appropriation accounts and should be submitted to department of state accounts, auditor general department and chief internal auditor. According to the financial regulation and treasury circulars the following accounts should be prepared by the government organizations such as,

- Annual Appropriation Accounts,

- Advance Account,

- Imprest Account,

- Deposit Accounts etc.

Most of the government organization does not prepare income statement, statement of financial position and cash flow statement in Sri Lanka.

\section{Public Assets Management Practices in Sri Lanka}

A huge amount of money spends on assets purchase for government organization. There are a lot of non-current assets procurement for the government organization. Due to that assets management play a vital role in the government organization of the Sri Lanka. According to the financial regulation every government organization has to do annual board of survey on its assets like stock counting and physical verification in the private sector. Board of survey is carried out by board of survey committee. Board of survey committee is appointed on before $15^{\text {th }}$ December of every year. The board composes with minimum two responsible officers. Board of survey committee has responsibility to verify stores and report on unserviceable stores of the government organization. There is two forms in board of survey such as form T \& A.66 for the verification of stores and form general 47 for reporting on unserviceable stores. Store officer and store keeper should be appointed for every government organization here generally store officer should be staff grade officer. Store keeper has responsibility to maintain the store of the government organization and store officer has responsibility to supervise store keeper and store of the government organizations of the Sri Lanka. 


\section{Public Financial Management Practices in Sri Lanka}

The Financial Regulations of the Government of Sri Lanka is a subject that has been assigned to the Minister of Finance by the President exercising the powers vested in him under Article 44(1) a of the Constitution of the Democratic Socialist Republic of Sri Lanka. Minister of finance has delegated his/ her powers to the secretary of the ministry of finance. He or she is the secretary to the treasury. Further deputy secretary of the treasury is the head of the treasury. Treasury has a major role in the public financial management. According to ministry of finance there are the following key departments each department under a director general.

- Department of National Budget

- Department of Fiscal Policy

- Department of Public Finance

- Department of Public Enterprises

- Department of State Accounts

- Department of External Resources

- Department of Development Finance

- Department of Information Technology Management

- Department of Legal Affairs

- Department of Management Service

- Department of Management Audit

- Department of Trade and Investment Policy

- Department of Treasury Operations

Public financial management of the country should be based on the financial regulations 1992, government gazette notifications, government circulars and administration regulations of the Sri Lanka. These financial regulations are binding on all government departments, statutory boards and similar institutions. All government officers are hereby required to acquaint themselves with the provisions of these regulations. Chapter three of the financial regulations clearly describes about financial management and accountability of the Sri Lanka. There are three key officers such as chief accounting officers, accounting officers and revenue accounting officers in the public financial management of the Sri Lanka. Minister of finance has the duty to account to parliament on all receipts and payments of the country. Therefore minister of finance appoints a secretary to each ministry as chief accounting officer. In addition to secretaries to ministries, the officers in charge of the departments specified in Article 52 (7) of the constitution and other departments not supervised by secretaries to ministries will be chief accounting officers. Chief accounting officer has the responsibility for supervising departmental financial transactions according to the directions of the treasury. 
Head of each department will be the accounting officer in respect of all the financial transactions of his department. As such, he is immediately responsible to, his chief accounting officer in the manner laid down in the financial regulations. The treasury will indicate from time to time the officers who will be responsible for the preparation of the estimates of revenue under the different heads, sub-heads, items and sub-items, and who will ultimately be accountable for variations between the estimates and actual collections. Such officers shall, for the purpose of these regulations, be referred to as revenue accounting officers. There are a several public officers involve in the public financial management. Especially head of the departments and government accountants play a major role of the public financial management in the Sri Lanka.

\section{Public Budget Preparation and Implementation in Sri Lanka}

Budget preparation is the key function of every country. Country's budget preparation is a big process. There is a separate department for the budget preparation for the Sri Lanka. It is department of national budget which operates under the treasury of Sri Lanka. Generally national budget is prepared for a year which is from $1^{\text {st }}$ January to $31^{\text {st }}$ December. According to department of national budget circular no. 2/2017 provides guidelines, and calls for budgets for the fiscal year 2018 to be formulated based on the performance-based budgeting approach.

Department of national budget has the responsibility to give proper guidelines to all the public sector's budget preparation and collect budgets from all the public sector organizations through the proper channel then department of national budget will accumulate received budget. National budget department will finalize the national budget as draft budget estimate. According to the constitution of the country, minister of finance has the responsibility to submit the draft budget estimates for the approval of cabinets then draft budget estimates will be submitted for the corrections, changes and approval in the parliament. Generally government accounts prepare the budget of their organization according to the available data and discussion with the head of the department. According to the financial management systems - Sri Lanka (2018), annual national budget calendar of the Sri Lanka can be seen as follow.

- Department of national budget issues budget call or budget letter to secretaries of line ministries, chief secretaries of provincial councils, and heads of departments setting guidelines and directions for annual budget preparation in July.

- Cabinet approves initial cabinet memorandum on the budget, indicating the government's overall revenue and expenditure position in August.

- Budget discussions are held with spending agencies, revenue departments, and other stakeholders in relation to allocations to sectors, ministries, other institutions, programs, and projects, based on priorities within the government's overall development framework and the firmed-up budget theme during August to September.

- Second cabinet memorandum is presented to the cabinet of ministers and appropriation bill is published in the gazette in October. 


\section{Macrothink}

Asian Journal of Finance \& Accounting

ISSN 1946-052X

2019, Vol. 11, No. 1

- At least 7 days after the publication of the appropriation bill: Bill is presented to Parliament (first budget reading).

- Budget details are presented to parliament and minister of finance and planning delivers budget speech (second reading of budget) in November.

- Second-reading debate is held and appropriation bill is put to a vote maximum of 7 days after budget speech (last week of November).

- Draft estimates for each line ministry are discussed separately with secretaries of relevant ministries (committee-stage debates) and approved maximum of 22 days from the end of the second reading debate (last week of November to third week of December).

- Appropriation act is endorsed by speaker (budget is passed in Parliament) in third week of December.

- Before the end of December, minister of finance and planning issues warrant(s) authorizing expenditure.

- Department of national budget issues expenditure authorization circular to spending agencies in last week of the December.

\section{Public Sector Accounting Standards in Sri Lanka}

According to Sri Lanka Public Sector Accounting Standards (2009), The Sri Lanka Public Sector Accounting Standards issued in 2009 by the Institute of Chartered Accountants of Sri Lanka are, with the permission of the International Federation of Accountants (IFAC), largely, based on the International Public Sector Accounting Standards published by IFAC. CA introduced four standards for the public sector in 2009 such as,

- $\quad$ SLPSAS 1 - Presentation of financial Statements

- $\quad$ SLPSAS 2 - Cash Flow Statements

- $\quad$ SLPSAS 3 - Accounting Policies, changes in Accounting Estimates and Errors

- $\quad$ SLPSAS 4 - Borrowing Cost

Sri Lanka public sector accounting standards volume II published by CA, Sri Lanka in 2012. It covers further six standards such as,

- SLPSAS 5 - The Effects of Changes in Foreign Exchange Rates

- SLPSAS 6 - $\quad$ Events After the Reporting Date

- SLPSAS 7 - $\quad$ Property, Plant \& Equipment

- $\quad$ SLPSAS 8 - Provisions, Contingent Liabilities and Contingent Assets

- $\quad$ SLPSAS 9 - Inventories

- $\quad$ SLPSAS 10 - $\quad$ Revenue from Exchange Transactions 


\section{$\Lambda$ Macrothink}

Asian Journal of Finance \& Accounting

ISSN 1946-052X 2019, Vol. 11, No. 1

CA, Sri Lanka is motivating accrual basis accounting and public sector accounting standards implementation in the Sri Lanka. CA, Sri Lanka provides award on Best Annual Report and Accounts Awards for the public sector. According to Sunday Observer News dated on $4^{\text {th }}$ November 2018, second best annual report and accounts award was organised by the Association of Public Accountants of Sri Lanka, the public sector wing of CA Sri Lanka in 2018. Twenty-six public institutions were honoured at the awards ceremony with nine public sector organisations winning the main awards which was categorised into nine sectors covering universities, research institutions, statutory boards, ministries, departments, provincial councils, urban councils, municipal councils and pradeshiya sabhas.

\section{b) Empirical Review}

Davor and Gorana (2010) tested the appropriateness of existing modified accrual accounting and financial reporting system in Croatian public healthcare sector. This study reveals that accounting information system contains discrepancies and constraints in assuring true and fair view of organization's financial position and performance. Analysis of the study confirmed low level of cost and managerial accounting methods development, and external and internal financial reporting convergence. Researcher argued that Croatian public healthcare sector represents a segmental accounting subsystem within the integral public sector accounting framework, where accruals implementation might prove justifiable.

Rozaidy, Siti, Rasid and Raman (2017) analysed the possible contextual and application gaps derived from the utilisation of van Helden and Northcott's (2010) method of study for classifying themes in published public sector's accrual accounting papers according to their research objectives. Objectives of the study were proposing new financial/management accounting techniques/approaches for public sector accrual accounting systems, examining the effectiveness of accrual accounting techniques/approaches, identifying the conditions for the successful/failure of the implementation of accrual accounting techniques/approaches and knowledge-building in understanding, explaining and critiquing the adoption and use of accrual accounting techniques/approaches, both theoretically and practically. Researchers were able to find which areas of study have received less attention and which areas have room for further exploration. The findings show that research objective explaining and critiquing the adoption and use of accrual accounting techniques/approaches was the most popular subject among the researchers, followed by research objective examining the effectiveness of accrual accounting techniques/approaches. Research objective identifying the conditions for the successful/failure of the implementation of accrual accounting techniques/approaches and knowledge-building in understanding is usually chosen as a complimentary focus, along with the two previous research objectives being mentioned earlier. Most of the papers are less directed towards research objective proposing new financial/management accounting techniques/approaches for public sector accrual accounting systems.

Tatjana (....) stated the public sector accounting as the ex post recording and reporting of financial operations of government represents the fundamental management process in public sector entities. Researcher pointed that countries are facing a challenge to improve the information served by public accounting for the state budgeting purpose, most often by 
reforming accounting principle from cash flow into accrual in time of financial and economic crisis. Researcher recommended that accrual principle obtains more transparent and complete review of the business activities and property of the users of public funds then cash principle does. This study analysed the three accounting models and principles of state budgeting in order to assess the connection between stages of accrual principle implementation and budgeting. Analysis of the study confirmed that regardless of the stage of accruals implementation in the national accounting legislation, the planning and execution of the state budgets is still on the cash principle.

Andrew (2010) reveals that a broad review of the public sector accounting research in recent years, including that undertaken in the United States. An analysis of this research found a methodological distinction between research undertaken in the US and that undertaken in the rest of the world. This study concluded that with an exhortation for PSAR researchers to explore multi paradigmatic methodologies in future research.

Rossana, Adriana, Roberta and Jorge (2013) this study evaluated the perceptions of internal and external users and preparers of accounting information in the Brazilian public sector regarding a change to an accrual based accounting system and the potential for such a system to provide informational benefits to decision-makers and managers of public entities. The results of the study confirmed that the survey respondents perceived accrual basis accounting as having the potential to provide informational benefits for decision-making within governmental agencies. Researchers suggested that the adoption of this new accounting system is not entirely driven by a mandatory requirement or pressure from international institutions. Differences in levels of perceived usefulness among different respondent groups recommended that actions taken by the managers of the Brazilian Accounting Standards Applied to the Public Sector to improve dissemination of information and implement training programs may be paying off because internal and external users were more likely than other respondents to perceive accrual basis accounting as having high potential for generating information for decision-making. Further this study noted that the need for public sector managers to focus the implementation process on the activities of other stakeholders to generate an environment that is receptive to this new paradigm.

Jane and James (2008) purpose of the study was to review and critique the field of public sector accounting research. Many nation states deliver essential public services. In recent times, many of these nations have been involved in programmes of "modernisation", which, in part, means that these public services now are significantly managed, delivered and governed by private and third sector organisations.

This study employed a literature-based analysis and critique of public sector accounting articles published in the selected journals from 1992 to 2006. From this, a descriptive meta-analysis of the characteristics of the research discussed. The descriptive analysis highlighted that among the research papers reviewed several interesting patterns emerged concerning public service research. Also, the dominance of Australasia and UK research was noted. The extent of research in different levels of government/jurisdiction indicated that the majority of research was organisationally based. Various functional types of accounting are considered, management 
accounting remained the most researched area of interest.

Tatjana (2015) the constant challenge countries face to improve the information served by public accounting due to the recent financial and economic crisis. The crisis has shown that accounting based on the accrual principle provides a more transparent and complete overview of business activities and assets than accounting based on the cash principle. The paper analysed and compared the accounting systems in Slovenia and Croatia in order to assess the conditions for transparent and management-oriented financial information, and the progress of the implementation of the accrual principle in budgeting. Findings of the study revealed that regardless of the stage of accrual implementation in national accounting legislation, the planning and execution of state budgets is still based on the cash principle.

Salah and Mahfuzul (2016) this study focused to review the public sector accounting research (PSAR). Through the review of the papers published from 1992 to 2015, the nature, trends and character of PSAR have been tried to identify. This review covered three justified aspects of PSA research have been used - theory initiation of reforming the PSA, practice of reforming the PSA and standards development for reforming the PSA. The review found that over the time, the trends of PSAR have been changed and have been enriched from different areas. Researchers found that while some researchers used to concentrate more on the adoption of developed standards, a number of contemporary researches concentrate on comparative adoption, innovation in practice and probable integration with the new areas.

\section{Statement of the Problem}

According to the literature review and working experience as government accountant, most of the government organization did not prepare the final accounts on accrual basis in the Sri Lanka. Public sector organizations are unable to calculate its total assets, liabilities, payables and receivables as organization wise. Further there is no proper software and record system for the assets management of public sector in Sri Lanka. There is a huge amount of money spend for the assets purchase in the public sector even though there is no proper method on assets management. According to the annual report (2017) ministry of finance, Sri Lanka, it can be seen that budget estimate of total revenue was Rs. 1,913,650,000,000 and actual total revenue was Rs. 1,845,017,336,787 further budget estimate of total expenditure was Rs. $2,962,212,371,000$ and actual total revenue was Rs. 2,603,105,058,303. According to the above figures it can be seen that there is problem in the public financial management, budget preparation and implementation in Sri Lanka. Finally problem statement of the study can be stated there is problem in the current public sector accounting practices and implementation of public sector accounting standards in Sri Lanka.

\section{Research Objectives}

Main objective of the study is to identify the perception of government accountant on current public sector accounting practices and implementation of public sector accounting standards in the Sri Lanka. The followings are the sub objectives of this study; 
- To find out the relationship between perception of government accountant on current public sector accounting practices and implementation of public sector accounting standards in the Sri Lanka.

- To find out the impact of perception of government accountant on current public sector accounting practices and implementation of public sector accounting standards in the Sri Lanka.

- To identify mean differences between perception of government accountant on current public sector accounting practices and implementation of public sector accounting standards in central government and provincial government of the Sri Lanka.

\section{Methodology}

\section{a) Sample}

This study is based on perception of government accountants in Sri Lanka. Researcher considered government accountants who are working in the central, provincial and local government in the Sri Lanka. Researcher selected 60 government accountants from central government, 30 government accountants from provincial government and 10 government accountants from local government through convenience sampling. This study covers totally 100 government accountants in the Sri Lanka. Response rate of this study is disclosed in Table 1 .

Table 1. Sample size and response rate

\begin{tabular}{|c|c|c|c|}
\hline Government Accountants & Sent & Returned & Response Rate \\
\hline Central Government & 60 & 24 & $40 \%$ \\
\hline Provincial Government & 30 & 10 & $33.33 \%$ \\
\hline Local Government & 10 & 01 & $10 \%$ \\
\hline \multicolumn{1}{|c|}{ Total } & $\mathbf{1 0 0}$ & $\mathbf{3 5}$ & $\mathbf{3 5 \%}$ \\
\hline
\end{tabular}

\section{b) Data Source}

This study is mainly based on primary data from government accountants in the Sri Lanka. Researcher developed 1-5 point likert scale questionnaire. Questionnaire covered statements for four major contents under the current public sector accounting practices such as financial reporting, public financial management, assets management and budget preparation and implementation. Developed questionnaire used to collect date from respondents of the study through Google form. Google survey form is one of the user friendly, very cost effective and green environment primary data collection techniques.

\section{c) Hypotheses}

This study considers the following hypotheses based on perception of government accountants 
in Sri Lanka.

H1: There is a significant relationship between perceptions of government accountants on current public sector accounting practices and the implementation of public sector accounting standards in the Sri Lanka.

H2: There is a significant impact of implementation of public sector accounting standards on public sector financial reporting practices in the Sri Lanka.

H3: There is a significant impact of implementation of public sector accounting standards on public sector assets management practices in the Sri Lanka.

H4: There is significant mean difference between perceptions of government accountants on current public sector accounting practices and implementation of public sector accounting standards in central government and provincial government of the Sri Lanka.

\section{d) Data Analysis Strategies}

Researcher did descriptive analysis and inferential analysis in this study. Mainly descriptive analysis used to reveal the mean value of perception of government accountants on current public sector accounting practices and implementation of public sector accounting standards in the Sri Lanka. Correlation, regression and Independent-Samples T Test performed to test the hypotheses of the study. Researcher used SPSS latest version for the data analysis of the study.

\section{Descriptive Analysis and Interpretation}

\section{a) Demographic Profiles of the Respondents}

Demographic profiles of the respondents are shown in the table 2, 3 and 4. Demographic profiles cover age, gender and working experience of the respondents of the study.

Table 2. Age of the Respondents

\begin{tabular}{|l|c|c|}
\hline Age & Number of Respondents & Response Rate \\
\hline Below 30 years & 02 & 06 \\
\hline $30-40$ years & 24 & 68 \\
\hline $40-50$ years & 08 & 23 \\
\hline $50-60$ years & 01 & 03 \\
\hline Total & $\mathbf{3 5}$ & $\mathbf{1 0 0 \%}$ \\
\hline
\end{tabular}

According to above table it can be seen that nearly 70 percentage respondents are 30 - 40 years old in this study. 
Table 3. Gender of the Respondents

\begin{tabular}{|l|c|c|}
\hline Gender & Number of Respondents & Response Rate \\
\hline Male & 20 & $57 \%$ \\
\hline Female & 15 & $43 \%$ \\
\hline Total & $\mathbf{3 5}$ & $\mathbf{1 0 0} \%$ \\
\hline
\end{tabular}

Table 3 shows that most of the respondents of the study are male.

Table 4. Working Experience of the Respondents

\begin{tabular}{|l|c|c|}
\hline Years & Number of Respondents & Response Rate \\
\hline $1-10$ years & 24 & $69 \%$ \\
\hline $10-20$ years & 11 & $31 \%$ \\
\hline Total & $\mathbf{3 5}$ & $\mathbf{1 0 0} \%$ \\
\hline
\end{tabular}

Most of the respondents working experience is one to ten years in this study.

\section{b) Reliability Analysis}

Table 5. Reliability Statistics (Cronbach's Alpha Test)

\begin{tabular}{|l|c|c|}
\hline Questions Title & Number of Questions & Cronbach's Alpha \\
\hline Financial Reporting & 27 & 0.825 \\
\hline Assets Management & 06 & 0.846 \\
\hline \multicolumn{1}{|c|}{ Preparation $\quad$ and } & 14 & 0.827 \\
\hline Public Financial Management & 07 & 0.680 \\
\hline $\begin{array}{l}\text { Budget } \\
\text { Implementation }\end{array}$ & 18 & 0.868 \\
\hline The Implementation of Public Sector & & \\
Accounting Standards & 72 & 0.928 \\
\hline Total & & \\
\hline
\end{tabular}




\section{Macrothink}

Asian Journal of Finance \& Accounting ISSN 1946-052X 2019, Vol. 11, No. 1

According to table 5 it can be seen that the score of Cronbach's Alpha range is 0.680 to 0.868 further Cronbach's Alpha for the total is 0.928 . It reflects that validity of the data which is high level in this study.

\section{c) Descriptive Analysis}

Table 6. Descriptive Analysis

\begin{tabular}{|l|c|c|c|c|c|}
\hline & Minimum & Maximum & Mean & $\begin{array}{c}\text { Std. } \\
\text { Deviation }\end{array}$ & Variance \\
\hline $\begin{array}{l}\text { Financial Reporting } \\
\text { Practices }\end{array}$ & 2.26 & 3.81 & $\mathbf{3 . 1 2 7}$ & 0.41402 & 0.171 \\
\hline $\begin{array}{l}\text { Assets Management } \\
\text { Practices }\end{array}$ & 1 & 4.5 & $\mathbf{2 . 7 1 9}$ & 0.7251 & 0.526 \\
\hline $\begin{array}{l}\text { Financial Management } \\
\text { Practices Sector }\end{array}$ & 2 & 4.36 & $\mathbf{3 . 3 9 5 9}$ & 0.49619 & 0.246 \\
\hline $\begin{array}{l}\text { Budget Preparation } \\
\text { and Implementation }\end{array}$ & 2 & 4.57 & $\mathbf{3 . 3 0 6 1}$ & 0.54799 & 0.3 \\
\hline $\begin{array}{l}\text { Public Standards } \\
\text { Accounting }\end{array}$ & 2 & 4.67 & $\mathbf{3 . 3 4 4 4}$ & 0.49833 & 0.248 \\
\hline \begin{tabular}{l} 
Implementation \\
\hline
\end{tabular}
\end{tabular}

According to the above table it can be stated that assets management practices are in very low level in the public sector. Financial management practices are high level in the public sector even though it can be seen that there is no any accounting practices and public sector implementation more than mean value 3.50. Perception of the accountant regarding current public sector accounting practices and implementation of the public sector accounting standards are in moderately agree level.

Table 7. Are you aware on the financial report preparation on accrual basis

\begin{tabular}{|l|l|c|c|c|c|}
\hline \multicolumn{2}{|c|}{} & Frequency & Percent & Valid Percent & $\begin{array}{c}\text { Cumulative } \\
\text { Percent }\end{array}$ \\
\hline \multirow{3}{*}{ Valid } & No & 1 & 2.9 & 2.9 & 2.9 \\
\cline { 2 - 6 } & Yes & 34 & 97.1 & 97.1 & 100.0 \\
\cline { 2 - 6 } & Total & 35 & 100.0 & 100.0 & \\
\hline
\end{tabular}


According to the table 7, it can be seen that more than 97 percentage of government accountants are aware on the accrual basis financial report preparation. It gives green signal that government accountants can prepare and understand accrual basis financial report.

Table 8. Did you prepare annual accounts on accrual basis in Sri Lankan public sector

\begin{tabular}{|l|l|r|r|r|r|}
\hline \multicolumn{2}{|c|}{} & Frequency & Percent & Valid Percent & Cumulative Percent \\
\hline \multirow{3}{*}{ Valid } & No & 27 & 77.1 & 77.1 & 77.1 \\
\cline { 2 - 6 } & Yes & 8 & 22.9 & 22.9 & 100.0 \\
\cline { 2 - 6 } & Total & 35 & 100.0 & 100.0 & \\
\hline
\end{tabular}

More than 77 percentage accountants did not prepare annual accounts on accrual basis in Sri Lankan public sector according to the above table 8 .

Table 9. Did you prepare annual accounts on accrual basis in Sri Lankan public sector * Working Station Cross tabulation

\begin{tabular}{|c|c|c|c|c|c|}
\hline & \multicolumn{3}{|c|}{ Working Station } & \multirow{3}{*}{$\begin{array}{r}\text { Total } \\
27\end{array}$} \\
\hline & & \multirow{2}{*}{$\begin{array}{c}\text { Central } \\
\text { Government } \\
22\end{array}$} & \multirow{2}{*}{$\begin{array}{c}\text { Provincial } \\
\text { Government } \\
4\end{array}$} & \multirow{2}{*}{$\begin{array}{c}\text { Local } \\
\text { Government } \\
1\end{array}$} & \\
\hline $\begin{array}{l}\text { Did you prepare annual } \\
\text { accounts on accrual basis }\end{array}$ & No & & & & \\
\hline $\begin{array}{l}\text { in Sri Lankan public } \\
\text { sector }\end{array}$ & Yes & 2 & 6 & 0 & 8 \\
\hline \multicolumn{2}{|l|}{ Total } & 24 & 10 & 1 & 35 \\
\hline
\end{tabular}

According to the above table 9, more than 50 percentage government accountants prepared annual accounts on accrual basis in provincial government public sector on the other hand only below than 9 percentage government accountants prepared annual accounts based on accrual basis in central government public sector of Sri Lanka.

\section{Inferential Analysis and Interpretation}

a) Correlation Analysis 
Table 10. Correlations

\begin{tabular}{|c|c|c|c|c|c|c|}
\hline & & FRP & AMP & PFMP & $\mathrm{BP}$ & IPSAS \\
\hline \multirow[t]{3}{*}{ FRP } & Pearson Correlation & 1 & $.481^{* *}$ & $.716^{* *}$ & .249 & $.367^{*}$ \\
\hline & Sig. (2-tailed) & & .003 & .000 & .149 & .030 \\
\hline & $\mathrm{N}$ & 35 & 35 & 35 & 35 & 35 \\
\hline \multirow[t]{3}{*}{ AMP } & Pearson Correlation & $.481^{* *}$ & 1 & $.795^{* *}$ & $.618^{* *}$ & $.344^{*}$ \\
\hline & Sig. (2-tailed) & .003 & & .000 & .000 & .043 \\
\hline & $\mathrm{N}$ & 35 & 35 & 35 & 35 & 35 \\
\hline \multirow[t]{3}{*}{ PFMP } & Pearson Correlation & $.716^{* *}$ & $.795^{* *}$ & 1 & $.525^{* *}$ & $.450^{* *}$ \\
\hline & Sig. (2-tailed) & .000 & .000 & & .001 & .007 \\
\hline & $\mathrm{N}$ & 35 & 35 & 35 & 35 & 35 \\
\hline \multirow[t]{3}{*}{ BP } & Pearson Correlation & .249 & $.618^{* *}$ & $.525^{* *}$ & 1 & $.361^{*}$ \\
\hline & Sig. (2-tailed) & .149 & .000 & .001 & & .033 \\
\hline & $\mathrm{N}$ & 35 & 35 & 35 & 35 & 35 \\
\hline \multirow[t]{3}{*}{ IPSAS } & Pearson Correlation & $.367^{*}$ & $.344^{*}$ & $.450^{* *}$ & $.361^{*}$ & 1 \\
\hline & Sig. (2-tailed) & .030 & .043 & .007 & .033 & \\
\hline & $\mathrm{N}$ & 35 & 35 & 35 & 35 & 35 \\
\hline
\end{tabular}

**. Correlation is significant at the 0.01 level (2-tailed).

*. Correlation is significant at the 0.05 level (2-tailed).

According to the correlation analysis of the study it can be seen that there is a significant relationship between perceptions of government accountants on current public sector accounting practices and the implementation of public sector accounting standards in Sri Lanka. Therefore H1 $_{1}$ is accepted in this study. Further it can be stated that through the proper and healthy implementation of public sector accounting standards, public sector accounting practices can be improved in the Sri Lanka.

b) Regression Analysis 
Table 11. Coefficients ${ }^{\mathrm{a}}$

\begin{tabular}{|c|c|c|c|c|c|c|}
\hline & & \multicolumn{2}{|c|}{ Unstandardized Coefficients } & \multirow{2}{*}{$\begin{array}{l}\text { Standardized } \\
\text { Coefficients } \\
\text { Beta }\end{array}$} & \multirow[b]{2}{*}{$\mathrm{t}$} & \multirow[b]{2}{*}{ Sig. } \\
\hline \multicolumn{2}{|c|}{ Model } & B & Std. Error & & & \\
\hline \multirow[t]{2}{*}{1} & (Constant) & 2.108 & .455 & & 4.635 & .000 \\
\hline & IPSAS & .305 & .135 & .367 & 2.264 & .030 \\
\hline
\end{tabular}

a. Dependent Variable: FRP

Table 11 reveals that implementation of public sector accounting standard is significantly impact on financial reporting practices of public sector in the Sri Lanka. That means, effective and efficient implementation of public sector accounting standard will lead for the significant positive impact on the financial reporting practices of public sector in the Sri Lanka. Therefore $\mathbf{H}_{2}$ is accepted in this study.

Table 12. Coefficients ${ }^{\mathrm{a}}$

\begin{tabular}{|c|c|c|c|c|c|c|}
\hline & & \multicolumn{2}{|c|}{ Unstandardized Coefficients } & \multirow{2}{*}{$\begin{array}{l}\text { Standardized } \\
\text { Coefficients } \\
\text { Beta }\end{array}$} & \multirow[b]{2}{*}{$\mathrm{t}$} & \multirow[b]{2}{*}{ Sig. } \\
\hline \multicolumn{2}{|c|}{ Model } & B & Std. Error & & & \\
\hline \multirow[t]{2}{*}{1} & (Constant) & 1.044 & .804 & & 1.298 & .203 \\
\hline & IPSAS & .501 & .238 & .344 & 2.107 & .043 \\
\hline
\end{tabular}

a. Dependent Variable: AMP

According to the above table 12, it can be seen that there is a significant impact of implementation of public sector accounting standards on public sector assets management practices in Sri Lanka. Therefore $\mathbf{H}_{3}$ is accepted in this study. Further public sector assets management can be improved through the effective and efficient implementation of the public sector accounting standards in Sri Lanka.

\section{c) Independent-Samples T Test}


Table 13. Group Statistics

\begin{tabular}{|c|c|c|c|c|c|}
\hline & Working Station & $\mathrm{N}$ & Mean & Std. Deviation & $\begin{array}{c}\text { Std. Error } \\
\text { Mean }\end{array}$ \\
\hline \multirow[t]{2}{*}{ FRP } & Central Government & 24 & 3.1127 & .43364 & .08852 \\
\hline & Provincial Government & 10 & 3.2185 & .34764 & .10993 \\
\hline \multirow[t]{2}{*}{ AMP } & Central Government & 24 & 2.6389 & .78122 & .15947 \\
\hline & Provincial Government & 10 & 3.0167 & .43355 & .13710 \\
\hline \multirow[t]{2}{*}{ PFMP } & Central Government & 24 & 3.3482 & .53714 & .10964 \\
\hline & Provincial Government & 10 & 3.5786 & .31307 & .09900 \\
\hline \multirow[t]{2}{*}{ BPI } & Central Government & 24 & 3.2202 & .53780 & .10978 \\
\hline & Provincial Government & 10 & 3.5571 & .53218 & .16829 \\
\hline \multirow[t]{2}{*}{ IPSAS } & Central Government & 24 & 3.2176 & .44351 & .09053 \\
\hline & Provincial Government & 10 & 3.6167 & .54650 & .17282 \\
\hline
\end{tabular}

Current public sector accounting practices are high level in provincial government rather than central government. As well implementation of public sector accounting standard is high level in provincial government than central government of the Sri Lanka. 
Table 14. Independent Samples Test

\begin{tabular}{|c|c|c|c|c|c|c|}
\hline & & \multicolumn{2}{|c|}{$\begin{array}{c}\text { Levene's Test for Equality } \\
\text { of Variances }\end{array}$} & \multicolumn{3}{|c|}{$\begin{array}{c}\text { t-test for Equality of } \\
\text { Means }\end{array}$} \\
\hline & & $\mathbf{F}$ & Sig. & $\mathbf{t}$ & df & $\begin{array}{l}\text { Sig. } \\
\text { tailed })\end{array}$ \\
\hline FRP & $\begin{array}{l}\text { Equal variances } \\
\text { assumed } \\
\text { Equal variances not } \\
\text { assumed }\end{array}$ & .853 & .363 & $\begin{array}{l}-.684 \\
-.750\end{array}$ & 20.999 & $\begin{array}{l}.499 \\
.462\end{array}$ \\
\hline AMP & $\begin{array}{l}\text { Equal variances } \\
\text { assumed } \\
\text { Equal variances not } \\
\text { assumed }\end{array}$ & 2.767 & .106 & $\begin{array}{l}-1.432 \\
-1.796\end{array}$ & 29.032 & $\begin{array}{l}.162 \\
.083\end{array}$ \\
\hline PFMP & $\begin{array}{l}\text { Equal variances } \\
\text { assumed } \\
\text { Equal variances not } \\
\text { assumed }\end{array}$ & 2.971 & .094 & $\begin{array}{l}-1.263 \\
-1.559\end{array}$ & $\begin{array}{r}32 \\
28.084\end{array}$ & $\begin{array}{r}.216 \\
.130\end{array}$ \\
\hline BPI & $\begin{array}{l}\text { Equal variances } \\
\text { assumed } \\
\text { Equal variances not } \\
\text { assumed }\end{array}$ & .029 & .867 & $\begin{array}{l}-1.669 \\
-1.677\end{array}$ & $\begin{array}{r}32 \\
17.079\end{array}$ & $\begin{array}{l}.105 \\
.112\end{array}$ \\
\hline IPSAS & $\begin{array}{l}\text { Equal variances } \\
\text { assumed } \\
\text { Equal variances not } \\
\text { assumed }\end{array}$ & .201 & .657 & $\begin{array}{l}-2.233 \\
-2.046\end{array}$ & $\begin{array}{r}32 \\
14.199\end{array}$ & .060 \\
\hline
\end{tabular}

According to the above table there is mean difference between perception of government accountant in provincial government and central government of the Sri Lanka. However there is no significant mean difference. Therefore $\mathbf{H}_{4}$ is rejected in this study. 


\section{Conclusion}

Today every country tries to adopt accrual basis accounting practices in public sector. There is a number of public sector accounting standards in the Sri Lanka. General treasury has a vital responsibility on public sector accounting practices and the implementation of public sector accounting standards in the Sri Lanka. According to the analysis of the study it can be seen that overall current public sector accounting practices and the implementation of public sector accounting standards are not in effective and efficient position based on the perception of government accountants. However current public sector accounting practices and the implementation of the public sector accounting standards are high level in provincial government rather than central government of the Sri Lanka. Government accountants suggested that proper awareness and training on public sector accounting standard implementation will lead to effective and efficient usage of the standards and accrual basis adoption in the public sector. Finally it can be concluded that current public sector accounting practices can be improved through the proper implementation of public sector accounting standards in the Sri Lanka.

\section{References}

Andrew, G. (2010). Contemporary public sector accounting research - An international comparison of journal papers. The British Accounting Review, 42, 75-87. https://doi.org/10.1016/j.bar.2010.02.006

Annual Report. (2017). Ministry of Finance Sri Lanka. Retrieved from: http://www.treasury.gov.lk/web/guest/publications/annual-report.

Davor, V., \& Gorana, R. (2010). Accounting System in Croatian Public Healthcare Organizations: an Empirical Analysis. Theoretical and Applied Economics, 17, 37-58. Retrieved from: https://www.researchgate.net/publication/46567511.

Financial Regulations of The Government of The Democratic Socialist Republic of Sri Lanka. (1992). Ministry of Finance Sri Lanka. Retrieved from: file://E:/2019\%20Research/Research\%20on\%20Public\%20Sector/PS/LR/FinancialRegulation-English.pdf.

Jane, B., \& James, G. (2008). Public sector to public services: 20 years of "contextual" accounting research. Accounting, Auditing \& Accountability Journal, 21, 129-169. https://doi.org/10.1108/09513570810854383

Jovanovič, T. (2015). Public Sector Accounting in Slovenia and Croatia. HKJU-CCPA, 15, 791814. Retrieved from: file://C:/Users/PC/AppData/Local/Temp/Jovanovic.pdf.

Rossana, G., Adriana, F., Roberta, L., \& Jorge, K. (2013). Accrual Basis Accounting in the Brazilian Public Sector: Empirical Research on the Usefulness of Accounting Information. Paper presented at the 12th USP Congress of Controllership and Accounting. Retrieved from: file://C:/Users/PC/AppData/Local/Temp/en_05.pdf.

Rozaidy, M., Siti, N., Rasid, M., \& Raman, N. (2017). Accrual Accounting in Public Sectors: 


\section{Macrothink}

Asian Journal of Finance \& Accounting ISSN 1946-052X 2019, Vol. 11, No. 1

Possible Contextual and Application Gaps for Future Research Agenda. Asian Journal of Finance \& Accounting, 9, 245-260. https://doi.org/10.5296/ajfa.v9i1.10968

Salah, U., \& Mahfuzul, H. (2016). A Literature Review on Public Sector Accounting Research. The Jahangirnagar Journal of Business Studies, 5, 35-52.

Sri Lanka Public Sector Accounting Standards. (2009). Institute of Chartered Accountants Sri Lanka. Retrieved from: file://E:/2019\%20Research/Research\%20on\%20Public\%20Sector/PS/LR/publicsectoraccost d2009.pdf.

Sri Lanka Public Sector Accounting Standards Volume II. (2012). Institute of Chartered Accountants Sri Lankar from: file://E:/2019\%20Research/Research\%20on\%20Public\%20Sector/PS/LR/SLPSASVolII.pdf 